\title{
Disciplining Creativity: Habit, System, and the Logic of Late Sixteenth-Century Poetics
}

\author{
Michael Hetherington
}

'Quid est Poëtica? Est facultas benè scribendi uersus'. ${ }^{1}$ We need only consider for a moment the limitations of this definition, and the range of available alternatives furnished by early modern European writers on the subject, to remind ourselves how varied and how undisciplined the discipline of poetics was in the period addressed by the articles in this issue. This particular definition is furnished by Johann Thomas Freige, a German follower of the French logician and pedagogic reformer Petrus Ramus; Freige is heeding the dictates of his master in offering statements and precepts of immense clarity and simplicity. Ramus never wrote a textbook on poetics, and when Freige and other followers remedied this lack as they tried to complete his curricular project they produced treatises of rather limited scope: they tended to deal only with matters of versification, because other elements of poetic practice - particularly the invention and arrangement of material - were addressed by other arts, namely logic and rhetoric. ${ }^{2}$ The reasons for writing about poetics in this way themselves arose from the discipline of logic, and specifically from its role in regulating the formulation and teaching of the arts. Ramus understood arts as collections of precepts, formulated and arranged according to rules borrowed, somewhat illicitly, from Aristotle's work on the logic of syllogistic demonstration. As a result of this logical clarity and restraint, each art — as a body of theory, but not in practice — was supposed to be discrete and self-sufficient, a methodically structured representation of human competence easily assimilated by students. ${ }^{3}$

The works on poetics produced in obedience to this methodology are, predictably enough, rather thin and disappointing, having been suffocated by misguided rigour. Nevertheless, the idea that gave rise to these works - namely, that it should be possible to write about the poetic art in a coherent and logical way - was potent and widespread in the sixteenth century. George Puttenham, for example, defends not only the vernacular literature he sought to describe and encourage but also his own activity as a literary theorist by arguing that English poetics might be 'reduced into a method of rules and precepts' or 'a certain order of rules prescribed by reason and gathered by experience'; and William Scott explicitly offers

\footnotetext{
${ }^{1}$ Johann Thomas Freige, Paedagogus (Basel: Sebastian Henricpetri, 1582), sig. i2r: 'What is poetics? It is the faculty of writing verses well'.

${ }^{2}$ For another example of Ramist poetics, see Moritz von Hesse-Kassel, Poetices methodice conformatae libri duo (Kassel: Wilhelm Wessel, 1598); compare the post-Ramist example, within broadly the same methodological tradition, in Johann Heinrich Alsted, Encyclopaedia Septem tomis distincta, 2 vols (Herborn: [s.n.], 1630), I, 50970 .

3 See, for example, Petrus Ramus, Dialecticae libri duo, Audomari Talaei praelectionibus illustrati (Paris: Andreas Wechel, 1566), pp. 9, 224-37, 367-69; for the clearest exposition of this doctrine, see Walter J. Ong, Ramus, Method and the Decay of Dialogue (Cambridge, MA: Harvard University Press, 1958), pp. $258-63$.
} 
a poetics regulated by the dictates of 'the logicians'. ${ }^{4}$ These writers belong to the corpus of English poetics that will form the main focus of this article - a much smaller theoretical canon than exists in several continental literatures. Puttenham and Scott, unlike most of the other writers commonly grouped within that canon, offer fully elaborated arts of poetry; their logical and methodological claims cut to the heart of the question of poetics' status and respectability as a coherent, distinct, and teachable discipline. However, these references to the idea of a logically determined poetics are belied by a great deal of methodological reticence in the execution of works of poetic theory in sixteenth-century England. This article argues that the hypothesis of a logical poetics informed and stimulated critical inquiry in the period, but remained largely and tellingly unfulfilled. Furthermore, the tendency of early modern poetics to render the question of methodology an object of knowing play is concomitant with another, wider tendency to ironize its own normativity: poetics pretends to legislate for acts of poetic making, but almost always draws attention to the limitations of its authority and ability to do so. The apparent methodological uncertainty of works of poetics often masks something subtler and more circumspect, as they make a virtue of their relatively marginal, undisciplined status and highlight aspects of poetic skill which cannot be accommodated within a methodical system. This is not, in itself, a radical claim; but this article suggests that thanks to the rediscovery of Scott's Model of Poesy we are now better positioned, as literary historians, to define some of the logical and conceptual issues that shaped the field.

\section{Problems in Writing the History of Poetics}

To acknowledge the methodological coyness of English poetics is to say something about the way the subject was constituted as a field of knowledge in this period, and to recognise its contingency and fragmentation. It is therefore fitting to begin by considering how works of poetics came to exist, and what they were trying to achieve; and here the literary historian immediately encounters a profound yet instructive problem of generalization. The relatively small size of the canon of what we might call English poetics in the sixteenth century, and the lack of dialogue among its different participants, restricts the ways we can study the subject. ${ }^{5}$ It prevents us from applying some of the historical methodologies that have been brought to bear on continental poetics, and particularly on its neo-Latin and Italian instantiations. We cannot, for English poetics, write a large-scale narrative that tracks subtle changes of emphasis and points of debate from treatise to treatise as Bernard Weinberg was able to do for the vast body of Italian material; nor can we very meaningfully identify discrete topics like the marvellous or even the nature of mimesis for the richly analytic and historical treatment

\footnotetext{
${ }^{4}$ George Puttenham, The Art of English Poesy, ed. Frank Whigham and Wayne A. Rebhorn (Ithaca, NY: Cornell University Press, 2007), p. 95; William Scott, The Model of Poesy, ed. Gavin Alexander (Cambridge: Cambridge University Press, 2013), p. 6.

${ }^{5}$ This observation is shared by Henry S. Turner, The English Renaissance Stage: Geometry, Poetics, and the Practical Spatial Arts 1580-1630 (Oxford: Oxford University Press, 2006), p. 85, and by Gavin Alexander's introductory essay in Scott, Model, p. xli.
} 
provided by Baxter Hathaway, again for the Italian canon. ${ }^{6}$ The sheer mass of Italian material, much of it in manuscript, enabled in these studies a kind of thick description of a lively field of cultural production, a field which had been enabled and sustained by social and institutional conditions alien to the English context (including, for example, frequent lectures on poetics in the universities and academies). Both Weinberg and Hathaway stress the enormity and complexity of Italian criticism, which was highly varied in both its form and content, and in the range of geographical and institutional locations in which it was pursued. They also openly concede that they provide possible rather than infallible or exhaustive routes through that territory. ${ }^{7}$ Nevertheless, Weinberg in particular found it possible to delineate poetics' fundamental species of thought or modes of inquiry, the rules of the poetological game, much as an anthropologist might identify the tacit rules and structures that subtend individual manifestations of social behaviour. Besides his overarching arguments about the changing relations between Horatian and Aristotelian criticism, and about the stimulus provided by contemporary vernacular challenges to ancient genre theory, Weinberg argues that the history of Italian criticism is the history of its 'methodological and logical bases', including such tools of sixteenth-century thought as the four causes, the three arts of the trivium, techniques of argument and exposition, and distinctions between theory and practice, practice and production, scientific knowledge and probable opinion. This approach has not generally been available to, or adopted by, scholars of English literary criticism: those who have tried to write the history of English poetics have tended either to note, at a very general level, its pervasive debt to rhetoric, or have been forced to acknowledge that it was 'confused, intermittent, and wholly unregulated', 'tentative and occasional'. ${ }^{8}$ Understanding of its 'methodological and logical bases' has been elusive because, even more than in Italy, English poetics was never a well-defined discipline to which a writer might simply add: instead, its terms, methods and aims had always to be established afresh.

Let us take the most fêted early modern work of English poetics by way of example. We can, of course, celebrate Philip Sidney's Defence of Poesy as an original and compelling case for the value - indeed, the necessity — of imaginative literature, with a power that transcends its historical moment; but, if we try to measure its reception as an index of the magnitude of that power, we find it difficult to trace concretely or precisely the Defence's impact on later literary theory and practice (William Scott's extensive use of Sidney in the Model being a newly discovered and notable exception). ${ }^{9}$ The cultural debates in which the

\footnotetext{
${ }^{6}$ Bernard Weinberg, A History of Literary Criticism in the Italian Renaissance, 2 vols (Chicago: University of Chicago Press, 1961); Baxter Hathaway, The Age of Criticism: The Late Renaissance in Italy (New York: Cornell University Press, 1962); Baxter Hathaway, Marvels and Commonplaces: Renaissance Literary Criticism (New York: Random House, 1968).

${ }^{7}$ See, in addition to the aforementioned works, Bernard Weinberg, 'Nota Critica Generale', in Trattati di Poetica e Retorica del Cinquecento, 4 vols (Bari: Laterza, 1970-74), I, 541-62.

8 J.W.H. Atkins, English Literary Criticism: The Renascence (London: Methuen, 1947), pp. 2, 139

${ }^{9}$ Witness the relative paucity of comment on the Defence's afterlife in the most comprehensive study of Sidneian reception to date: Gavin Alexander, Writing After Sidney: The Literary Response to Sir Philip Sidney 1586-1640 (Oxford: Oxford University Press, 2006); for isolated examples of such engagement, see pp. 131-32, 274-75, 281. See also Colin Burrow, 'Combative Criticism: Jonson, Milton, and Classical Literary Criticism in England', in The Cambridge History of Literary Criticism, Volume III: The Renaissance, ed. Glyn P. Norton (Cambridge: Cambridge University Press, 1999), pp. 487-99 (p. 489) for a brief suggestion about Sidney’s influence on Jonson.
} 
Defence participated did not belong solely or squarely within the field of poetics per se: the Defence may articulate important theoretical doctrines, including the nature of poetic mimesis, but it is born of a less coolly theoretical moment, provoked by Stephen Gosson's attack on poetic immorality in The Schoole of Abuse (1579), to which Thomas Lodge also responded in print. ${ }^{10}$ Rather than try to place the Defence in a narrative of disinterested poetological debate, which seems to strain at the available evidence, we may entertain the possibility of agreeing with Sidney himself in deeming the Defence an 'ink-wasting toy', and so distrust its sincerity or the grandeur of its claims; or, alternatively, we may attribute its arguments to Sidney's adherence to one or other prevailing school (or to several such schools) of thought outside the field of literary theory. ${ }^{11}$ Thus for Forrest Robinson the Defence depends primarily on a 'visual epistemology' with both an ancient and an early modern intellectual heritage, including a significant role for Ramism; for Robert Stillman, Sidney's poetics bears a large debt to the thought of Philipp Melanchthon, offering a model of literary cognition calculated to serve both the worldly and the redemptive ends of an irenic, cosmopolitan reformed Christianity. ${ }^{12}$ Such important contextualizations of the text each offer us a slightly different Defence, placing it within Sidney's individual intellectual world while helpfully fragmenting our sense of the wider poetological field of which it is an instance.

The necessary injunction that arises from all this, surely, is to heed both the syncretic complexity and the sheer contingency of each particular text, and so not to overlook the heterogeneity of English poetics, a field which (like its Italian and French counterparts) includes notes and observations on versification, defences, university orations, courtly manuals, scholarly treatises, paratextual notes, and rhetorical and educational theory: no two texts of Elizabethan poetics do quite the same thing in quite the same way. To admit this heterogeneity is to resist a natural temptation to reify the different types of writing about poetry from this period into a single body of theory or critical discourse, however useful such a coherent corpus would be as a hermeneutic guide. We can see this temptation at work in Brian Vickers' assertion that 'writers in this period had a perfectly coherent theory of literature': writing at a high level of generality, Vickers reduces the wide-ranging and subtle early modern thinking about poetics to a simple 'union of rhetoric and ethics', a single 'psychology of reading', and an unproblematic 'agreement between writers and readers over the representation of good and evil'. ${ }^{13}$ We must, instead, read against the grain of works whose natural idiom encourages a kind of generalisation: in presuming to make general statements about literature,

For an overview of the Defence's early reception, noting 'the paucity of late sixteenth- and early seventeenthcentury comments' on the work, see Martin Garrett, Sidney: The Critical Heritage (London: Routledge, 1996), pp. 36-39.

${ }^{10}$ For an account of Sidney's response to Gosson, see Arthur F. Kinney, 'Parody and Its Implications in Sydney's Defense of Poesie', Studies in English Literature 1500-1900, 12 (1972), 1-19.

${ }^{11}$ Philip Sidney, A Defence of Poetry, in Miscellaneous Prose of Sir Philip Sidney, ed. Katherine Duncan-Jones and Jan van Dorsten (Oxford: Clarendon Press, 1973), pp. 59-121 (p. 121).

12 Forrest G. Robinson, The Shape of Things Known: Sidney's 'Apology' in its Philosophical Tradition (Cambridge, MA: Harvard University Press, 1972), pp. 113-20; Robert E. Stillman, Philip Sidney and the Poetics of Renaissance Cosmopolitanism (Aldershot: Ashgate, 2008), pp. 63-64, 103-22.

${ }^{13}$ English Renaissance Literary Criticism, ed. Brian Vickers (Oxford: Clarendon Press, 1999), pp. vii-viii, 14, 53. 
or to posit generally applicable laws, poetics makes (or seems to make) a claim to universality, encompassing a whole field of literary production, both actual and hypothetical, within macrocosmic conceptual structures like mimesis, rhetorical invention and affect, and the system of literary kinds. In avoiding such philosophically tempting generalisation, we might instead notice how local and particular the practice of poetics was in early modern England. Poetics took place, so to speak, in prefaces to individual works, as a mediation between their particularity and theory's generality; ${ }^{14}$ or in letters to particular persons, like Eduardo Donati, the possibly fictional recipient of George Gascoigne's Certayne Notes of Instruction (1575); ${ }^{15}$ or in manuscripts circulated among coteries, a category which included Sidney's Defence before its publication in two slightly different printed forms in 1595. Sometimes, poetics took place so privately that it has been hidden from literary history: the most egregious example of this is William Scott's Model of Poesy, dedicated to Sir Henry Lee in 1599 and kept among the papers of his heirs until the twenty-first century; but there are other, lesser examples of materials on poetics in manuscript which have largely escaped scholarly attention.

Two such texts can be drawn, for illustration, from the manuscript holdings of a single institution. In the Huntington Library we find copied into a multigenerational miscellany in a mid-Elizabethan hand a fragmentary late-medieval tract De metro, apparently a kind of theoretical supplement to an interest in Latin versification (and, in particular, the writing of epigrams and epitaphs) witnessed in other parts of the manuscript. ${ }^{16}$ This volume belonged to Thomas Buttes (d. 1593), a Norfolk magistrate and son of Henry VIII's physician William Buttes (c. 1485-1545); it was given to Thomas by the antiquary Robert Talbot (1505/6-1558) and given by him in turn to his kinsman Francis Aung[i]er (1558-1632). ${ }^{17}$ The tract on versification gives us a sense of the many private, instrumental, antiquarian, and practical uses to which poetics might be put in this period, far removed from ambitious programmes for cultural betterment and philosophically informed theory. In another Huntington manuscript, a student notebook dating from the second and third decades of the seventeenth century and apparently originating in the English Catholic community at Douai, we find among texts on logic and rhetoric both a Tractatus de generibus poematum and a commentary In Quintum Horatium fflaccum de arte poetica. ${ }^{18}$ The commentary on Horace is immediately preceded by a charming mock-inscription, recording the date (1623) of the teaching which gave rise to the notebook, 2708 years after the fall of Troy, 2303 years after the foundation of Rome, and three years after the second Trojan War — a reference to some literal or metaphorical horseplay ('A

\footnotetext{
${ }^{14}$ See, for example, George Whetstone's dedicatory preface to his The right excellent and famous Historye, of Promos and Cassandra (London: Richard Jones, 1578), sigs. A2r-3r.

${ }^{15}$ George Gascoigne, 'Certayne Notes of Instruction', in A Hundreth Sundrie Flowres, ed. George W. Pigman III (Oxford: Clarendon Press, 2000), pp. 454-62; on the identity of Donati, see Pigman's note at p. 732.

${ }^{16}$ Huntington Library MS 8, fols. 215v-218r. The same text is also found in Corpus Christi College Cambridge MS 386; for a transcription see James Nasmith, Itineraria Symonis Simeonis et Willielmi de Worcestre. Quibus accedit tractatus de metro, in quo traduntur regulae a scriptoribus medii aevi in versibus Leoninis observatae (Cambridge: J. Archdeacon, 1778), pp. 379-88.

${ }^{17}$ On the Buttes family and the wider cultural interests to which this manuscript bears witness, see Karl Josef Höltgen, 'Sir Robert Dallington (1561-1637): Author, Traveler, and Pioneer of Taste', Huntington Library Quarterly, 47 (1984), 147-77 (pp. 149-53).

${ }^{18}$ Huntington Library, Ellesmere Collection, MS EL 34/B/10, fols. 50r-56r, 105r-107r.
} 
Bello Troiano secondo, Horse-fairico primo, Anno III'). Local colour is rarely more colourful than this. Neither of these texts can be said to have made a significant intervention in early modern literary culture; nor are they innovative or original. Nevertheless, in their embeddedness in particular local milieux they bear comparison with the more canonical texts of Renaissance poetics. Even when Philip Sidney or George Puttenham made apparently normative statements about the whole field of poetic production, they were answering questions and imperatives local to their special cultural moments and circumstances, from the Sidneian literary milieu in places like Wilton and Penshurst to the vexed personal situation of a social outsider mired in scandal and litigation; Puttenham's claims to national relevance and courtly counsel need to be recognized for the rhetorical strategies that they are. ${ }^{19}$ We need, for English and continental literatures alike, a local history of early modern poetics to set alongside the grander historical narrative that tracks the more philosophically engaging and theoretically powerful shifts in the ideational strategies of the evolving field of literary theory. ${ }^{20}$

Such a fine-grained and particular history of poetics, untroubled by specious expectations about the consistency of the field, would also heed the different conceptual frameworks and governing methodologies that underpin each text. The familiar presence in multiple works of Horatian, Ciceronian, Augustinian and Neoplatonic commonplaces, and varying degrees of immediate or mediated Aristotelianism, can give the impression of an easygoing eclecticism or syncretism, a consequence-free blending of ideas within an epistemic framework large and flexible enough to contain multitudes. Debates about the nature and degree of the synthesis present in a given text are vexed: in the case of Sidney's Defence, for instance, some scholars, like S.K. Heninger, are content to arrive at reasonably categorical statements about Sidney's poetics (for him, a deeply Aristotelian doctrine of imitation); others, like O.B. Hardison, argue for a radical disjuncture between its incompatible humanist and neoclassical doctrines; still others seek a pragmatic or rhetorical unity that transcends such divisions. ${ }^{21}$ Such synthetic complexity can result from the acts of partial or failed understanding that took place when one theorist read another, something that Gavin Alexander identifies in Puttenham's idiosyncratic use (resulting in 'candid head-scratching') of Julius Caesar Scaliger's Poetices libri septem: Puttenham's book both is and is not an attempt to write

\footnotetext{
${ }^{19}$ For these crucial elements of Puttenham's biography, see especially Steven W. May, 'George Puttenham's Lewd and Illicit Career', Texas Studies in Literature and Language, 50 (2008), 143-76. See also the introduction to Puttenham, The Art of English Poesy, pp. 49-69.

${ }^{20}$ A kind of claim for such localism was made long ago in Vernon Hall's argument that in Italy, France and England alike poetics was an epiphenomenon of social life; but Hall's tendency is to generalise rather than particularise, seeing almost all literary criticism as essentially aristocratic and cosmopolitan. See Vernon Hall, Renaissance Literary Criticism: A Study of its Social Content (New York: Columbia University Press, 1945).

${ }^{21}$ S.K. Heninger, Jr., Sidney and Spenser: The Poet as Maker (University Park, PA: Pennsylvania State University Press, 1989), pp. xi, 221, 223-306; O.B. Hardison, 'The Two Voices of Sidney's Apology for Poetry', English Literary Renaissance, 2 (1972), 83-99; Martin N. Raitiere, 'The Unity of Sidney’s Apology for Poetry', Studies in English Literature, 1500-1900, 21 (1981), 37-57. For some, of course, this question is the result of Sidney’s deliberate irony: see Ronald Levao, 'Sidney’s Feigned Apology', PMLA, 94 (1979), 223-33. On Sidney’s eclecticism, see further Turner, The English Renaissance Stage, pp. 85-90 (noting that Heninger himself, in his several studies of early modern poetics, places variable emphases on different elements of Sidney's theory). Turner offers a reliable overview of Sidney's diverse sources, although his skepticism about Sidney's direct knowledge of Aristotle's Poetics has been powerfully challenged by Micha Lazarus, 'Sidney's Greek Poetics', Studies in Philology, 112 (2015), 504-36.
} 
English poetics within a Scaligerian paradigm. ${ }^{22}$ It is, indeed, helpful to ask of early modern poetics some of the questions that Alasdair MacIntyre has so influentially asked of the history of ethics. MacIntyre diagnoses in post-Enlightenment moral philosophy a radical inability to arrive at agreement on moral questions, thanks to the simultaneous presence in the field of ethical debate of several incompatible paradigms. Some of these paradigms are, indeed, broken, living on only in the terminology of moral inquiry but historically uprooted from the conceptual structures and social frameworks in which those terms made sense. ${ }^{23}$ I suggest that the writer on poetics in the late sixteenth century was in a similar (if less extreme) position to MacIntyre's post-Enlightenment ethicist: there were different ways of even beginning to say something about the subject, and different lexical registers in which to do so.

\section{Scott's Model of Poesy: New Routes into the History of English Poetics}

We can see this at work in one relatively coherent and intellectually confident example. William Scott's recently rediscovered Model of Poesy explicitly undertakes to articulate a normative, rule-based poetics, structured according to the dictates of those whom he vaguely calls 'the logicians'; but as I have argued elsewhere, behind the Model's admirably rigorous and lucid logical structure lies a fusion—or, perhaps, a confusion —of ways of talking about poetics. ${ }^{24}$ The Model defines poetry very clearly as 'an art of imitation, or an instrument of reason, that consists in laying down the rules and way how in style to feign or represent things, with delight to teach and to move us to good'. ${ }^{25}$ Here, the word 'art' very clearly denotes the structure of rules and precepts which teaches one how to write poems, and Scott distinguishes this objective artefact of the human intellect from the less easily described state or habit possessed by the fully trained poet, and from the natural talent which makes that habit possible: 'in every art there must be a disposition and apt ability of nature before the habit or settled quality that reduceth the works thereof into being' ${ }^{26}$ This distinction is somewhat muddied by Scott's insistence that his understanding of an 'art' (a 'frame and body of rules compacted and digested by reason out of observation and experience, behoveful to some particular good end in our civil life') is derived from Aristotle; for in fact this closely renders not an Aristotelian but a Stoic definition of art, which had been widely popularized in the sixteenth century by the highly successful logic textbook written by Philipp Melanchthon. ${ }^{27}$ For the Stoics, whose

\footnotetext{
22 Sidney's 'The Defence of Poesy' and Selected Renaissance Literary Criticism, ed. Gavin Alexander (London: Penguin, 2004), p. 360; see too Gavin Alexander, 'Sidney, Scott, and the Proportions of Poetics', Sidney Journal, 33 (2015), 7-28 (pp. 11-13).

${ }^{23}$ For the original and most influential formulation of this thesis, see Alistair MacIntyre, After Virtue: A Study in Moral Theory (London: Duckworth, 1981); see too Alasdair MacIntyre, Whose Justice? Which Rationality? (London: Duckworth, 1988), p. 166, for a clear formulation of MacIntyre's understanding of the difficulties of deciding between claims made by rival traditions of thought.

${ }^{24}$ Michael Hetherington, ““An Instrument of Reason”: William Scott’s Logical Poetics’, forthcoming in Review of English Studies, 67 (2016).

${ }^{25}$ Scott, Model, p. 6.

${ }^{26}$ Scott, Model, p. 8.

${ }^{27}$ Scott, Model, p. 7.
} 
definition survived in texts by Lucian, Quintilian and others, an art (technē) was a system (systema) of observations - transformed by human reason into precepts - used in conjunction in the service of some definite human purpose. ${ }^{28}$ For Aristotle, by contrast, techne was primarily a productive habit aided by right reason (hexis meta logou alèthous poiētikē). ${ }^{29}$ Aristotle also offered a parallel understanding of techne as an eidos or image present in the mind of an artificer and then realized, by the exercise of skill, in his material medium, be it words, wood, stone or, in the case of a doctor, a human body in which the physician restores an eidos of health. ${ }^{30}$ These two latter concepts of techne focus less on an easily stated propositional content than on something which, though rational, is more complicatedly located in behaviour. In short, the classical tradition offered Scott and his peers multiple ways of talking about the nature of artistic skill, each of which overlapped in different ways with other logical, pedagogical, ethical and even metaphysical doctrines. ${ }^{31}$

The distinction between habit and system in concepts of art would, in the decades after Scott, be scrutinized in late-humanist, post-Ramist educational theory. Scott's continental contemporary Bartholomaüs Keckermann, whose textbooks would enjoy significant popularity in England later in the seventeenth century, acknowledged the difference between habit and system in his logical primer, first published in $1599 .{ }^{32}$ In another work, he notes that there are two mental powers by which we acquire the habits of different disciplines ('per quas [...] disciplinarum habitum acquirimus'): one is simply the correct understanding of precepts, the other their application to the goal or end of the discipline. Not everyone who learns precepts immediately possesses the correspondent skill ('nec omnes ii, qui praecepta perdidicerunt, statim eam habent promptitudinem'). ${ }^{33}$ Keckermann's follower in the post-Ramist encyclopaedic tradition, Johann Heinrich Alsted, would further theorize the link between habit and system by seeing them as two aspects of the same phenomenon, as 'disciplina interna' and 'disciplina externa'. ${ }^{34}$

Scott's treatise bears witness to a desire to elide the difference between these habitual and systematic understandings of art. Moreover, at multiple points in the Model, the actual subject of Scott's discussion is neither the system of rules, nor the poet's habit, but something else, the 'faculty' of poesy: 'in every faculty there is required [...] the nature or mind disposed,

\footnotetext{
${ }^{28}$ Lucian, Peri parasitou, in Opera, ed. M.D. MacLeod, 4 vols (Oxford: Clarendon Press, 1972-1987), II, 14274 (p. 146); Quintilian, Institutionis oratoriae libri duodecim, ed. Michael Winterbottom, 2 vols (Oxford: Clarendon Press, 1970), I, 120 (2.17.41); Philipp Melanchthon, Erotemata dialectices, in Philippi Melanthonis opera quae supersunt omnia, ed. Karl Gottlieb Bretschneider and Heinrich Ernst Bindseil, 28 vols (Halle: Schwetschke, 1834-60) XIII, 507-752 (col. 537).

${ }^{29}$ Transliterated from Aristotle, Ethica Nicomachea, ed. Ingram Bywater (Oxford: Clarendon Press, 1890), p. 117 (1140a10).

${ }^{30}$ Aristotle, Metaphysica, ed. Werner Jaeger (Oxford: Clarendon Press, 1957), pp. 139-41 (1032a28-b31).

${ }^{31}$ For a similar emphasis on the importance of the rich Aristotelian lexis of techne to early modern poetics, if directed towards slightly different conclusions, see Turner, The English Renaissance Stage, pp. 45-49.

${ }^{32}$ Bartholomaüs Keckermann, Praecognitorum logicorum tractatus tres, in Operum omnium quae extant tomus primus (Geneva: Petrus Aubertus, 1614), cols. 75-160 (col. 90).

${ }^{33}$ Bartholomaüs Keckermann, Praecognitorum philosophicorum libri duo, in Operum omnium quae extant tomus primus, cols. 1-68 (col. 21).

${ }^{34}$ Alsted, Encyclopaedia, I, 50.
} 
as the subject for art to work upon'. 35 'Faculty', like 'habit', denotes a mental state, related to a particular capacity for action or production. Facultas - a term we have already encountered in Freige's definition of poetica, with which this article began - was the common Latin analogue for the Greek term dunamis, best known to students of the history of literary theory from the beginning of Aristotle's Rhetoric, which defines its eponymous subject as the faculty of discovering the available means of persuasion in relation to any matter of discussion or debate. ${ }^{36}$ When Scott set about writing the Model in 1599 there was a lively tradition of debate about the relative merits and purposes of these and other terms for describing the arts. To take one contemporary example, the young Dutchman Gerardus Joannes Vossius, who would go on to become one of the leading scholars of his day and the author of a compendious midseventeenth-century work on poetics, distinguished in his commencement exercise for the degree of Master of Arts in 1598 between the art of rhetoric, which deals in precepts, and the corresponding faculty, which is more fully immersed in oratorical practice:

Rhetorica duobus modis accipitur pro arte sermonem ornandi, et pro facultate oratoria. Illius scopus est ornate loqui; officium, praecepta tradere de ornatu orationis. [...] At Oratoriae facultatis finis est persuadere dictione, et officium, bene dicere, sive dicere ad persuadendum accommodate. ${ }^{37}$

In spite of, or perhaps in light of, his awareness of the particular valences of these terms, Vossius found that something different was required in the case of poetics:

Poetica non est ars, sed facultatum quidam quasi cinnus; tam multa hinc inde emendicat. $^{38}$

While Vossius shares with Freige the identification of poetics as a facultas, his rejection of poetics' status as an art is an acknowledgement of the speciousness of attempts, including those of the Ramists, to reduce poetic skill to any simple set of precepts. Vossius's own poetics, as published several decades later, does announce itself as an art of poetry, but of a highly complex kind, in terms of its taxonomic rigour, its sense of literary history, and its account of technical skill and the labours of art. ${ }^{39}$

Scott and Vossius, writing within a year of each other in different European countries at the end of a century in which literary theory and criticism had rapidly proliferated and developed, are both caught within the plurality of terms and concepts which might be brought

\footnotetext{
${ }^{35}$ Scott, Model, p. 9.

${ }^{36}$ Aristotle, Ars Rhetorica, ed. W.D. Ross (Oxford: Clarendon Press, 1959), p. 5 (1355b25-26).

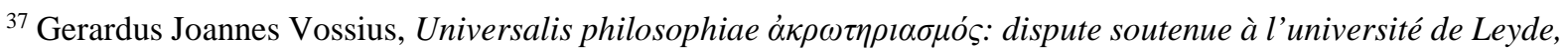
le 23 février 1598, ed. Modestus van Straaten (Leiden: Brill, 1955), p. 56: 'Rhetoric is understood in two ways: as the art of embellishing speech, and as the oratorical faculty. The aim of the first is to speak elaborately, and its function is to provide precepts for elaborate speech. But the end of the oratorical faculty is to persuade through speaking, and its function is to speak well, or to speak in a manner suited to persuasion’ (my translation).

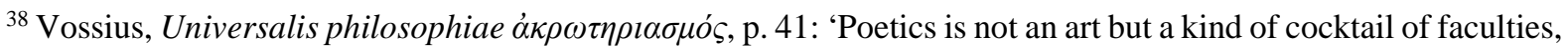
[because] it borrows so many things from different places’ (my translation).

${ }^{39}$ See Gerardus Joannes Vossius, De artis poeticae natura ac constitutione liber (Amsterdam: Ludovic Elzevir, 1647) and Poeticarum institutionum libri tres (Amsterdam: Ludovic Elzevir, 1647).
} 
to bear on poetics. However, the philosophical and terminological complexities in Scott's treatise should not be overstressed; indeed, they do not fatally undermine its theoretical power, but in many ways add to the richness of its meditation on the nature of the poet's skill. The availability to Scott of many words and concepts which answer the basic question 'what is art?' enables in the Model a certain theoretical suppleness, an ability to shift the exact focus of discussion from moment to moment. Like Quintilian, his favourite rhetorical source, Scott schematizes a field of human practice but remains aware that habitus, and the work or practice that it enables, stands distinct from such a schema as an emergent property which is both its summation and goal. ${ }^{40}$ Nevertheless, these terminological shifts do exemplify a more widespread methodological difficulty in early modern poetics. Scott succeeds, or almost succeeds, in tidying up the complex classical inheritance of thinking about artistic skill within the rational structure he builds with the help of 'the logicians'; and by so avowedly joining the pedagogical mainstream - that is, in treating poesy as a subject of teachable 'doctrine', and following logical procedures to make such doctrine effective - Scott throws into stark relief the persistent refusal of his English predecessors and contemporaries to do the same. As a result, the recent discovery and publication of his work helps to alleviate some of the literaryhistorical difficulty, alluded to earlier in this article, caused by the relative sparsity of English poetics: Scott answers a need which had been alluded to by numerous writers (including Gascoigne, Sidney, Puttenham, Harvey, Harington, Campion and Daniel), and in so doing he gives us a clearer, more coherent sense of what was at stake in each of these theorists' work.

\section{Julius Caesar Scaliger and the Limits of Poetic Theory}

Before giving an account of the issues that Scott helps us to diagnose in these writers, it will be instructive to consider their manifestation in the single most influential and authoritative continental poetics of the period, Julius Caesar Scaliger's Poetices libri septem (1561), which was an important source-text for Scott, Sidney, and Puttenham, and for the very first published work of English Renaissance poetics, Richard Willes's De re poetica (1573). Scaliger's book has a reputation as the high-water mark of early modern attempts to treat poetics fully and systematically, dealing in exhaustive detail with the classical literary inheritance but also offering taxonomic rigour in order to manage the sheer complexity of its data. There are, as we shall see, important exceptions to Scaliger's systematic orderliness. Scaliger gives his readers some reason to expect a scrupulously logical poetics in the prefatory letter to his son Sylvius. He sets his literary theory in the context of his other major work, De causis linguae latinae, in which he claims to have provided, for the very first time, a philosophically respectable account of grammar:

scripsimus [...] desumptis a Philosopho principiis pro confessis: quod in omni scientia fit inferiore. Philosophiae vero sanctiones, quae universae naturae sunt

\footnotetext{
${ }^{40}$ For an excellent account of Quintilian's concept of habit, see James J. Murphy, 'Roman Writing Instruction as Described by Quintilian', in A Short History of Writing Instruction, ed. James J. Murphy, $3^{\text {rd }}$ edn. (New York: Routledge, 2012), pp. 36-76.
} 
administrae, huic aptavimus arti, quae sine illius legibus atque praescriptionibus, ante nos quam parum fuerit vera ars. ${ }^{41}$

As the letter goes on, he relates his new work on poetics to his principal predecessors in the art - Aristotle, Horace, and Vida - but observes that each of these leaves something to be desired in respect of methodology. As Bernard Weinberg and Luc Deitz have argued, Scaliger can be thought of as an 'Aristotelian' theorist not in terms of the substantive content of his poetic doctrine (which in many ways contradicts that of the Poetics) but in his use of the logical and methodological tools of Aristotelian philosophy, including the categories and the four causes. ${ }^{42}$ Even so, a reader expecting philosophical clarity and consistency in Scaliger's Poetices libri septem, or the kind of 'vera ars' he claims to have provided for grammar, will be disappointed.

Poetices libri septem does have a structure: four books of theory are followed by two books of criticism, which are offered as a model for the kind of imitation and discrimination required in anyone who wishes to transform mere talent and knowledge into fully-fledged poetic skill. The four books of theory loosely depend upon the four causes: the formal cause of poetry is the rational conceptual content mimetically represented in the poem; the material cause is metrical language; the efficient cause is the poet; and the final cause or purpose is to teach with pleasure ('docere cum delectatione') or to make human life more ordered ('vt [...] humana vita compositior fiat'). ${ }^{43}$ However, these causes are not clearly mapped onto the different books; and Scaliger's acknowledgement that this is, in fact, his method is given in statements scattered throughout the work, rather than being explained explicitly at the outset. ${ }^{44}$ Never does Scaliger provide a definition of poesy of the kind offered by Philip Sidney and William Scott, and his apparently definitive statements are often themselves obscure, despite their vaunted clarity; one might even deem them obfuscatory and ludic if this were not so plainly belied by Scaliger's avowed seriousness as a thinker. A prime example of the paradoxical openness and untidiness of Scaliger's apparently serious and philosophically rigorous language comes during his wide-ranging second chapter, which deals with the name 'poeta', the origin of poems and poesy, and their efficient, formal and material causes:

Poema est opus ipsum: materia, inquam, quae fit. Poesis autem, ratio ac forma Poematis. [...] Est igitur Ilias, Poema: Homerus, Poeta: Ratio \& Forma qua Margites facta est, Poesis. Poetice vero scientia, id est, Habitus ex dispositione praeceptionum, quibus docemur ad conformationem hanc, quam poesin

\footnotetext{
${ }^{41}$ Julius Caesar Scaliger, Poetices libri septem (Lyon: Antoine Vincent, 1561), sig. a2v: 'I wrote according to recognized principles selected from the Philosopher [i.e. Aristotle], as is done in every lower discipline. I have applied the ordinances of philosophy, which are the handmaids of the whole of nature, to this art, which without those laws and precepts has scarcely, before me, been a true art' (my translation).

${ }^{42}$ See Bernard Weinberg, 'Scaliger versus Aristotle on Poetics', Modern Philology, 39 (1942), 337-60; Luc Deitz, 'Julius Caesar Scaliger's Poetices libri septem (1561) and his Sources', in Studi Umanistici Piceni, 14 (1994), 91-101; Luc Deitz, “'Aristoteles imperator noster...”? J.C. Scaliger and Aristotle on Poetic Theory’, International Journal of the Classical Tradition, 2 (1995), 54-67; Luc Deitz, 'Scholastic Logic and Renaissance Poetics: A Few Observations on J.C. Scaliger's Poetices libri septem', in Forms of the "Medieval" in the "Renaissance", ed. George Hugo Tucker (Charlottesville, VA: Rockwood Press, 2000), pp. 49-62.

${ }^{43}$ Scaliger, Poetices libri septem, pp. 347, 80.

${ }^{44}$ Scaliger, Poetices libri septem, pp. 5-6, 55, 80.
} 
appellamus. Ita habes causas tres. Materiam, Formam, Efficientem: \& in superiori commentario Finem, id est, Imitationem, sive ulteriorem finem, doctionem. ${ }^{45}$

At the centre of this quotation is a sentence which brilliantly captures the deep tension between habit and system at the heart of this article, a tension which the language and methodology of poetic theory consistently fail to resolve, even when at their most logical and precise. 'Poetice' is defined as a 'scientia', a kind of knowledge, and knowledge, in turn, is defined as a kind of habit; here Scaliger is broadly following Aristotle's identification of knowledge or epistèmē as one of the five intellectual virtues, the habits or hexeis by which we obtain different kinds of truth. ${ }^{46}$ It is not quite clear, however, whether Scaliger is using 'scientia' strictly, or whether (as so often happens in Neo-Latin and in early modern English) 'science' is deployed in a broader sense, encompassing not just epistēmē but technē too. A further ambiguity arises from the fact that the knowledge or habit is not straightforwardly identifiable with the arrangement of precepts which must in some way constitute its content, but arises from or out of that arrangement; Scaliger's Latin preposition, 'ex', bears a large but indefinite conceptual burden in this sentence. The knowledge of poetics is aligned not with poetological precepts themselves but with their arrangement or disposition in some kind of structure; but it is the plural precepts, rather than the singular disposition by which ('quibus') we are taught. And what are we taught? We are taught something called 'conformatio'; or, rather, we are taught 'ad conformationem', towards or perhaps for the sake of 'conformatio', a formula which places emphasis on the process of teaching and learning rather than on any simple model of didactic transfer from doctrine to disciple. It is not wholly clear whether the 'habitus' is the same as the 'conformatio', or whether the latter phenomenon somehow emerges from the former. 'Conformatio' itself is a word with multiple possible senses. Vitruvius uses it (and its cognate forms) to denote the rational plans of buildings, or, indeed, the structure of ordered constellations within the coherent universe. ${ }^{47}$ In Cicero's Brutus and Orator it can mean an arrangement of words or thoughts; and in his De natura deorum, a 'conformatio animi' is a mental image or concept (including things which may be imagined but which lack real-world referents). ${ }^{48}$ This cognitive sense of the word is broadly echoed in Cicero's Topica, in which an abstract noun is understood as a conformatio marked and imprinted in the intellect ('quaedam conformatio insignita et impressa intellegentia'). ${ }^{49}$ This sense of 'conformatio', as a state of the mind, shades into a

\footnotetext{
45 Scaliger, Poetices libri septem, pp. 5-6: 'I say that the poem is the work itself, the substance which is made. Poesis is the reason and form of the poem. Thus the Iliad is a poem, Homer is a poet, and the reason and form according to which the Margites was written is poesis. Poetics, to be sure, is a science, that is, a habit [emerging] from the arrangement of [those] precepts by which we are taught that conformation which we call poesis. You thus have three causes, material, formal, and efficient; and in the previous chapter [I provided] the final cause, which is either imitation or its ultimate end, teaching' (my translation).

46 Aristotle, Ethica Nicomachea, p. 116 (1139b12-18).

${ }^{47}$ Vitruvius, On Architecture, ed. and trans. Frank Granger, 2 vols (Cambridge, MA, 1931), I, 282-83 (5.6.1); II, 212-13 (9.1.2).

${ }^{48}$ Cicero, Brutus. Orator, ed. and trans. G.L. Hendrickson and H.M. Hubbell, rev. edn (Cambridge, MA, 1962), pp. 122-23 (Brutus, 37.140-41), 408-9 (Orator, 39.136); Cicero, De natura deorum. Academica, ed. and trans. H. Rackham, rev. edn (Cambridge, MA, 1951), pp. 102-3 (De natura deorum, 1.38.105).

${ }^{49}$ Cicero, De inventione. De optimo genere oratorum. Topica, ed. and trans. H.M. Hubbell (Cambridge, MA, 1949), pp. 400-1 (Topica, 5.27).
} 
more specifically educational one, denoting a disposition achieved through discipline: examples are found in Cicero's Pro Archia and De officiis. ${ }^{50}$

The uncertainty of Scaliger's statement provoked some of his readers to simplify or clarify its meaning when they used it in their own works of poetic theory. An early English reader of Scaliger has this to say:

Est igitur Poëta metricae imitationis, sive operis eiusmodi effector. Opus ipsum quod efficitur, Poëma. Poësis, ratio atque Poëmatis forma. Denique ars qua docemur, \& ad hanc instituimur conformationem, quam Poësin diximus, Poetice est. ut sit gratia exempli, Homerus Poëta, Ilias Poëma, ratio, forma, atque ingenii conformatio secundum quam Ilias facta est, Poësis; habitus ipse praeceptis artis, studio, \& exercitatione comparatus, Poëtice. ${ }^{51}$

Richard Willes adds to his Scaligerian master-text the notion of 'ingenii conformatio' to make clear that 'poesis' is the product of a mental state, an ordered or heightened formation (or conformation) of the poet's cerebral resources. From this clarification emerges a clearer distinction between 'poetice' (the general habit possessed by accomplished poets) and 'poesis' (the product or activity of that habit on each particular occasion of composition). Several decades later, Gerardus Joannes Vossius would refashion Scaliger's words in an apparent attempt to clarify and simplify his meaning: 'poëtice vero sit habitus ipse praecepta ad poësin disponens'. ${ }^{52}$ Vossius's reworking of the formula interestingly retains the notion of arrangement or disposition, but sets it to work in a different way. Scaliger's definition of poetics sounds like a piece of unambiguous doctrine, clearing away lexical confusion in order to facilitate a more precise understanding of the subject; but Willes's and Vossius's creative interactions with Scaliger's formula confirm - if any confirmation were needed - that it offers little of the clarification which its apparently confident declarative style seems to promise. This is not because it is lightly, ironically or playfully meant, but because the terms which Scaliger employs are inherently slippery, and because, more fundamentally, the relation between the objectifiable science of poetics, the habit possessed by the poet, and the actual act of making are obscure, recursive and circular. His sentence points towards a deep philosophical difficulty in modelling the link between theory and practice, knowledge and action.

\footnotetext{
${ }^{50}$ Cicero, Pro Archia. Post reditum in senatu. Post reditum ad Quirites. De domo sua. De haruspicum responsis. Pro Plancio, ed. and trans. N.H. Watts (Cambridge, MA, 1923), pp. 22-23 (Pro Archia, 7.15); Cicero, De officiis, ed. and trans. Walter Miller (Cambridge, MA, 1913), pp. 372-73 (3.25.96).

${ }^{51}$ Richard Willes, 'De re poetica', in his Poematum liber (London: Richard Tottel, 1573), sig. ${ }^{2}$ A6v: 'The poet, then, is the producer of a metrical imitation or of some such work. The work itself which he produces is the poem; poesis is the method and form of the poem. Finally the art by which we are taught and instructed in that conformatio that we call poesis is poetics. For example, Homer is a poet, the Iliad a poem, and the reason, form and conformation of mental ability according to which the Iliad was made is poesis. Poetics is the habit itself, obtained through artistic precepts, study and practice' (my translation).
}

52 Vossius, De artis poeticae natura ac constitutione liber, sig. C3v: 'poetics is that habit which arranges/determines the precepts which lead to poesis' (my translation). 


\section{The Avoidance of System: A Topos in English Poetics}

William Scott, recognising that these challenges are an essential part of any comprehensive poetics that seeks to account for the reality of the creative act, answered them by emulating a certain Scaligerian seriousness and by adopting a carefully articulated and entirely selfconscious methodological structure. In contrast, most English theorists of the preceding decades seemed happier to exploit the ludic potential of such language and methodology. Scott's committed attempt to provide a poetics that might pass the censure of 'the logicians' answers a need which had been playfully acknowledged by George Puttenham when, towards the beginning of The Art of English Poesy, he sought to justify not only vernacular literature itself but also its capacity to sustain, and to be improved by, theory and doctrine:

if poesy be now an art, and of all antiquity hath been among the Greeks and Latins, and yet were none until by studious persons fashioned and reduced into a method of rules and precepts, then no doubt may there be the like with us. [...] If again art be but a certain order of rules prescribed by reason and gathered by experience, why should not poesy be a vulgar art with us as well as with the Greeks and Latins $[\ldots] ?^{53}$

Puttenham's definition of 'art' is a close rendering of the Stoic formula mentioned earlier in this article, promulgated by Melanchthon in his textbook on logic: 'ars est ordo certarum propositionum, exercitatione cognitarum, ad finem utilem in vita' ${ }^{54}$ There is, of course, a slight difference between the formula reported by Melanchthon and the version given by Puttenham: the latter writer speaks of rules where Melanchthon speaks of propositions, and while for Melanchthon it is the propositions which are in some way 'certain', for Puttenham this quality belongs to the 'order' itself. As we have already learned from our reading of Scaliger, it is perhaps unwise to take such differences too seriously: they speak more than anything else of the flexibility, or indeed the lability, of such philosophical language. In any case, having assertively posed this rhetorical question - indeed, having twice in quick succession told us what a normatively methodical or ordered art of poetry might look like — the remainder of Puttenham's treatise often seeks to back away from such grand doctrinal ambitions. The Art of English Poesy is certainly well ordered, but it does not quite amount to a system of precepts; Puttenham's justification for this is that his 'chief purpose [...] is for the learning of ladies and young gentlewomen, or idle courtiers', to which 'manner of minds nothing is more cumbersome than tedious doctrines and scholarly methods of discipline'. Having eschewed method he offers instead 'a new and strange model of this art, fitter to please the court than the school'. ${ }^{5}$ The longest single work of early modern poetics in England is thus one which knowingly hedges both its status as a logically determined 'certain order' and, in consequence, the normative or prescriptive claims of the rules, precepts and forms of knowledge which it offers us. As Derek Attridge pointed out in an influential essay, Puttenham manifests a certain

\footnotetext{
53 Puttenham, The Art of English Poesy, p. 95.

${ }^{54}$ Melanchthon, Erotemata dialectices, col. 537: ‘an art is an arrangement of certain propositions, learned through experience, [directed] toward some useful end in life’ (my translation).

${ }^{55}$ Puttenham, The Art of English Poesy, p. 243.
} 
perplexity about the circular relation of art and nature, a perplexity which in some way dooms his poetics to failure, even if his book as a whole claims other kinds of success; Daniel Javitch aligned this with Puttenham's gracious complaisance towards his courtly audience, rightly showing how Puttenham reinscribes questions of poetic art (and facile artlessness) in codes of social behaviour. ${ }^{56}$ As this article has suggested, the division between art and nature (unsatisfactorily bridged, as Attridge shows, by the supplementary phenomenon of decorum, which participates in both), is itself subject to a further, and almost equally radical, multiplicity in the concept of art itself.

Puttenham's oblique engagement with the language of logical method is shared by George Gascoigne's Certayne Notes of Instruction (1575), which also, like Puttenham's Art, uses the social provenance of its poetic precepts as an excuse for its lack of logical order. ${ }^{57}$ Gascoigne writes to the possibly fictional Eduardo Donati, avowing that the text has been compiled 'not so perfectly as I would'; and he reminds his other readers (the buyers of the book, The Posies of George Gascoigne Esquire, in which the Certayne Notes are printed) of the social particularity of its provenance, in ways which pointedly interrupt the text:

I will next advise you that you hold the just measure wherwith you begin your verse, I will not denie but this may seeme a preposterous ordre: but bycause I covet rather to satisfie you particularly, than to undertake a generall tradition, I wil not somuch stand upon the manner as the matter of my precepts. I say then, remember to holde the same measure wherwith you begin. ${ }^{58}$

Gascoigne's overt displacing of 'order' and 'manner' in the service of a particular interpersonal sharing of practical skill returns us to a point made earlier in this article: namely, that the methodological evasiveness of early modern poetics is often associated with its tendency to emphasise the personal or local at the expense of, or in the same breath as, general theory. Gascoigne emphasises the point towards the end of the Notes:

I had forgotten a notable kinde of ryme, called ryding rime [...]: but though it come to my remembrance somewhat out of order, it shall not yet come altogether out of time, for I will nowe tell you a conceipt whiche I had before forgotten to wryte: you may see (by the way) that I holde a preposterous order in my traditions, but as I sayde before I wryte moved by good wil, and not to shewe my skill. ${ }^{59}$

\footnotetext{
${ }^{56}$ Derek Attridge, 'Puttenham’s Perplexity: Nature, Art, and the Supplement in Renaissance Poetic Theory', in Literary Theory/Renaissance Texts, ed. Patricia Parker and David Quint (Baltimore: Johns Hopkins University Press, 1986), pp. 257-79; Daniel Javitch, Poetry and Courtliness in Renaissance England (Princeton: Princeton University Press, 1978), pp. 50-75.

${ }^{57}$ While The Art of English Poesy was not printed until 1589, and is thus a later work than Gascoigne's Certayne Notes, it is probable that the origins of Puttenham's theoretical and critical enterprise go back much further, to the late 1560s: see George Puttenham, The Arte of English Poesie, ed. Gladys Doidge Willcock and Alice Walker (Cambridge: Cambridge University Press, 1936), pp. xliv-liii. In any case, my survey of English poetics henceforth proceeds in a broadly chronological fashion.

58 Gascoigne, 'Certayne Notes of Instruction’, p. 455.

${ }^{59}$ Gascoigne, ‘Certayne Notes of Instruction’, p. 461.
} 
In fact, this directly contradicts Gascoigne's explicit promise, at the beginning of the Notes, 'to set downe [his] simple skill'. The absence of method or 'order' in the text is correlated with a process of error and forgetting: Gascoigne promises not a reified system of precepts but a more personal 'tradition' of his artistic skill—his habit, and habits, as a poet—but the consequent lack of what Puttenham termed 'certain order' seems to call that skill into question, to make it vulnerable, open, mutable. In many ways, Gascoigne’s self-presentation in the Notes adopts a Horatian pose, familiar from the Ars poetica (which is, of course, not simply a technical handbook, but a letter ad Pisones): poetic skill is not presented methodically, but as a series of interlinked observations and canons, drawn from experience into a loose but essentially open and malleable collection. The Italian theorist Francesco Robortello, among others, had explained Horace's lack of logical order or method precisely in terms of the fact that he was writing a letter. ${ }^{60}$ For some logically-minded early modern readers, Horace's evasion of rational order was egregious: Scaliger comments upon it; Giovanni Antonio Viperano (an important source for Scott) complains that Horace neglected the 'order of teaching' ('ordinem doctrinae'); and several writers reordered Horace's text to produce something more methodical. ${ }^{61}$

In E.K.’s paratextual gloss to Edmund Spenser's Shepheardes Calender (1579), Gascoigne is described as 'the very chefe of our late rymers, who and if some partes of learning wanted not (albee it is well knowen he altogether wanted not learning) no doubt would haue attayned to the excellency' of other 'famous Poets' ${ }^{62}$ It is precisely this fine balance between the possibility of learning and an ill-defined sense of lack that the Certayne Notes actively exploit. Spenser, along with Gabriel Harvey, would occupy a similar, if more demonstratively learned, position in their published correspondence on English versification (which is in many respects, whether accidentally or deliberately, a companion piece to the Calender). Writing as denizens of the world of university learning, Spenser (under the name Immerito) excitedly reports the development of 'certaine Lawes and rules of Quantities of English sillables' by Philip Sidney and his circle. ${ }^{63}$ As was the case with Gascoigne's Certayne Notes, it is not wholly clear which kind of certainty these laws possess: we cannot quite tell whether they are, as it were, 'leges certae'-definitive propositions of which Melanchthon might have approved — or simply 'leges quaedam', an incomplete set of laws with less totalizing ambitions. In any case, Immerito initiates an exercise in practical criticism which functions, by extension,

\footnotetext{
${ }^{60}$ Francesco Robortello, 'Paraphrasis in librum Horatii, qui vulgo de arte poetica ad pisones inscribitur', in his In librum Aristotelis de arte poetica explicationes (Florence: Lorenzo Torrentino, 1548), sig. aa2r.

${ }^{61}$ Giovanni Antonio Viperano, De poetica libri tres (Antwerp: Christophe Plantin, 1579), sigs. A2r-v. For the logical reordering of Horace's Ars poetica, see especially Andreas Kragius, Q. Horatii Flacci Ars Poetica, ad P. Rami dialecticam \& Rhetoricam, resoluta (Basel: Sebastian Henricpetri, 1583), and Johann Thomas Freige, Rhetorica, Poetica, Logica ad usum rudiorum in epitomen redactae (Nuremberg: Katharina Gerlach, 1580). See further Ann Moss, 'Horace in the Sixteenth Century: Commentators into Critics', in The Cambridge History of Literary Criticism, Volume III: The Renaissance, ed. Glyn P. Norton (Cambridge: Cambridge University Press, 1999), pp. $66-76$ (p. 75).

${ }^{62}$ Edmund Spenser, The Shorter Poems, ed. Richard A. McCabe (Harmondsworth: Penguin, 1999), p. 146.

${ }^{63}$ Edmund Spenser and Gabriel Harvey, Three proper, and wittie, familiar Letters: lately passed betwene two Vniuersitie men: touching the Earthquake in Aprill last, and our English refourmed Versifying (London: Henry Bynneman, 1580), sig. G3v.
} 
as a meditation on the very role of such laws in the field of literary production. Harvey comments of Immerito’s trimeters, for example:

I finde not your warrant so sufficiently good, and substauntiall in Lawe, that it can persuade me, they are all, so precisely perfect for the Feete, as your selfe ouerpartially weene. ${ }^{64}$

For all the literary critical energy that this conceptual framework unleashes, Harvey and Spenser pointedly refrain — in what is by now becoming a familiar pattern — from offering a logically ordered poetic doctrine based on propositions of unimpeachable certainty. Harvey writes that neither his own experience, nor the English language and its orthography, are yet sufficiently developed to permit such certainty:

Interim, credit me, I dare geue no Preceptes, nor set downe any Certaine General Arte: and yet see my boldenesse, I am not greatly squaimishe of my Particular Examples, whereas he that can but reasonably skil of the one, wil giue easily a shreude gesse at the other. ${ }^{65}$

Harvey and Spenser circle knowingly around the potential for such an art, which they are reluctant to outline in a systematic way, but whose existence in another, less reified form, as instantiated in particulars and in their own skilful speculations, is strongly intimated. In this context, the idea that logic might have some role in disciplining this inchoate skill is cited with a strange mixture of scholarliness and light-heartedness:

But to let this by-disputation passe, which is already so throughly discoursed and canuassed of the best Philosophers, and namely Aristotle, that poynt vs, as it were with the forefinger, to the very fountaines and head springes of Artes, and Artificiall preceptes, in the Analitiques, and Metaphysikes: most excellently set downe in these four Golden Termes, the famoussest Termes to speake of in all

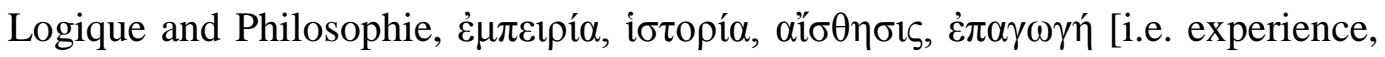
observation, sense-perception, induction]. ${ }^{66}$

The role of logic in effecting the transformation of mere experience into certain rules is exaggeratedly praised but never enacted by the text.

Philip Sidney's Defence of Poesy is not generally thought of as a work concerned with logical systematizing; but its suggestion that Sidney himself is 'a piece of a logician', able to resist specious arguments, both primes us to be on our dialectical guard against sophistry and, as Spenser and Harvey had done, wryly prompts readers to contemplate logic's role as a tool

\footnotetext{
${ }^{64}$ Spenser and Harvey, Three proper, and wittie, familiar Letters, sig. H4r.

${ }^{65}$ Spenser and Harvey, Three proper, and wittie, familiar Letters, sig. D4v. On the 'curious way' in which 'these letters establish Gabriel Harvey as a successor to an earlier generation of Cambridge humanists [...] by dwelling on [his] refusal to teach', see Jennifer Richards, 'Gabriel Harvey, James VI, and the Politics of Reading Early Modern Poetry’, Huntington Library Quarterly, 71 (2008), 303-21 (p. 305).

${ }^{66}$ Spenser and Harvey, Three proper, and wittie, familiar Letters, sig. E1r.
} 
for poetological inquiry. ${ }^{67}$ Sidney does argue that rationality has an important role to play in the improvement of English literary culture: 'they that delight in poesy itself should seek to know what they do, and how they do; and especially look themselves in an unflattering glass of reason, if they be inclinable unto it'. This is not quite an endorsement of the role of logic in poetic theory; indeed, this statement is made in support of the argument that poetic skill is to a large degree innate rather than teachable, rendering methodical doctrine somewhat futile. It is, however, a powerful assertion of the importance of theoretical rationalisation in managing an otherwise impulsive or unexamined creative practice. Shortly afterwards, Sidney adopts a lexis close to that of mainstream contemporary pedagogy:

the highest-flying wit [must] have a Daedalus to guide him. That Daedalus, they say, both in this and in other, hath three wings to bear itself up into the air of due commendation: that is, art, imitation, and exercise. But these, neither artificial rules nor imitative patterns, we much cumber ourselves withal. Exercise indeed we do, but that very fore-backwardly: for where we should exercise to know, we exercise as having known; and so is our brain delivered of much matter which never was begotten by knowledge. ${ }^{68}$

Sidney seems to argue that the use of artificial rules would benefit English poetry, although we cannot help but detect a note of reservation in his choice of the word 'cumber', as if those rules would be a heavy burden to bear; recall that Puttenham also spoke of 'scholarly methods of discipline' as 'cumbersome' to his courtly readers. Sidney's sense that there might be a more proper relationship between theory and practice, knowledge and skill, than currently obtains in English poesy is playfully put; he does not, of course, write a fully-fledged art of poesy, but operates instead in an apologetic mode which absolves him of any duty to lay down the cumbersome rules whose necessity he posits. Once again a logically and pedagogically normative art is envisioned but remains hypothetical.

A little later in the century, John Harington's 'Briefe apologie of poetrie', published among the prefatory material in his translation of Ariosto’s Orlando Furioso (1591), confirms that the consistent refusal of English writers to offer a committed, logical, scholarly and serious poetics had become, by then, something of a topos. Harington writes, tongue firmly in cheek:

Neither do I suppose it to be greatly behoofull for this purpose to trouble you with the curious definitions of a Poet and Poesie and with the subtill distinctions of their sundrie kinds nor to dispute how high and supernatural the name of a Maker is, so christned in English by that unknowne Godfather that this last yeare save one, viz. 1589, set forth a booke called the Art of English Poetrie, [...] for as for all or the most part of such questions I will refer you to Sir Philip Sidneys Apologie, who doth handle them right learnedly, or to the forenamed treatise where they are discoursed more largely and where as it were a whole receit of Poetrie is prescribed

\footnotetext{
67 Sidney, A Defence of Poetry, p. 73.

${ }^{68}$ Sidney, A Defence of Poetry, pp. 111-12.
} 
with so manie new named figures as would put me in great hope in this age to come would breed manie excellent Poets. ${ }^{69}$

Harington displaces the labour of logic — of 'curious definitions' and 'subtill distinctions' onto his two predecessors, who, as we have seen, are somewhat less rigorous in their own logic than Harington here allows. Moreover, his allusion to The Art of English Poesy, while superficially an endorsement, is coupled with a potent sense of the ridiculousness of Puttenham's enterprise, which Harington describes in terms of conceptual, rhetorical and enumerative excess. Harington's apparent hope that the abundance of Puttenham's prescriptions for writing might create a corresponding abundance of poets - a pointedly specious parallelism - highlights the problem that no order of poetic precepts is itself sufficient to inculcate artistic skill.

We have identified a strain of thought running through English poetics, whereby the very enterprise comes to be defined in terms of its failed engagement with the normative doctrinal practices prescribed by early modern logic. This phenomenon has become much clearer to our literary-historical eyes thanks to the recent rediscovery of Scott's Model, whose attempts to make poetic skill a subject of 'doctrine' highlight the pervasive unease about doctrine in other writings in the field. These writers share a sense that poetic creation is ineffably more complex, more immediate, and less knowable than the epistemological claims of art can comprehend. Works of poetics persistently undo their claims to systematic completeness, reinscribing theory and practice alike in a more personal and contingent world of work, memory and habit.

Thomas Campion's Observations in the Art of English Poesie (1602) adopts a quasiscientific idiom of demonstration and proof to describe the theoretical work it performs in the field of versification, but ends with a display of methodical lack. Campion can have the final, unfinal word:

These rules concerning the quantity of our English sillables I haue disposed as they came next into my memory, others more methodicall, time and practice may produce. In the meane season, as the Grammarians leaue many sillables to the authority of Poets, so do I likewise leaue many to their iudgements; and withall thus conclude, that there is no Art begun and perfected at one enterprise. FINIS. ${ }^{70}$

St John's College, University of Oxford

\footnotetext{
${ }^{69}$ Robert McNulty (ed.), Ludovico Ariosto's Orlando Furioso: Translated into English Heroical Verse by Sir John Harington (Oxford: Clarendon Press, 1972), p. 2.

${ }^{70}$ Thomas Campion, Observations in the Art of English Poesie (London: Richard Field, 1602), sig. D2r.
} 